\title{
Modeling the Value of Double Storey Terrace Houses Using Summation Method
}

\author{
Zurina Mahmood, Azhari Yahya and Maheran Mohd Jaffar \\ Faculty of Computer and Mathematical Sciences, Universiti Teknologi MARA, Shah Alam, Selangor Darul Ehsan, Malaysia \\ Correspondence Author: Zurina Mahmood, Faculty of Computer and Mathematical Sciences, Universiti Teknologi MARA, Shah Alam, Selangor Darul Ehsan, \\ Malaysia
}

Received date: 22 April 2019, Accepted date: 22 July 2019, Online date: 25 August 2019

Copyright: (C) 2019 Zurina Mahmood et al.2019. This is an open-access article distributed under the terms of the Creative Commons Attribution License, which permits unrestricted use, distribution, and reproduction in any medium, provided the original author and source are credited.

\begin{abstract}
The values of the real estate assets are increasing through the years based on the Malaysian price index. To determine the value of a house one can apply for valuation done by the government body which can be tedious and time consuming or one can hire private appraisers that can be costly and the methods used are different from one another. The purpose of this study is to propose a new valuation model for double-storey terrace houses that can be used for all. The doublestorey terrace houses in the state of Johor were used as a case study. In modeling the formula, the land and the physical structure of the real estate asset were determined separately. Land value was obtained by using the TOPSIS method while the physical structure value was by using the cost approach as a basis. Then, both were combined by using the summation method to become a hybrid model. The assumptions of the model were identified. The result shows the valuations are strongly positive correlated with the market prices. In conclusion, this model is suitable for appraising a double-storey terrace house.
\end{abstract}

ds: Valuation, Real Estate, Hybrid Model

\section{INTRODUCTION}

Across Asia, the fundamentals of real estate asset markets remain strong throughout 2013 based on the transaction volumes rising into the fourth quarter of the year, despite the uncertain economic trend [1]. This shows the real estate asset market is gaining attention in Asian countries, including Malaysia. The average house price for all types of houses in Malaysia hit RM302,716 in second quarter 2015 and has been increasing for the last four quarters [2]. The highest price of a house in Malaysia was recorded in Kuala Lumpur at RM 710,089 followed by Selangor while Perlis noted as the lowest price is at RM151,904.

Real estate asset or property comprises of land and the buildings on it [3]. It also includes the natural resources of the land, such as livestock and farmed crops, flora and fauna, water and minerals. Land means the land surface, the entire underlying layer, and space above the area [4].

The valuation of real estate asset is required to provide an opinion or conclusions and can be expressed in the form of a mathematical model. Real estate asset is evaluated or assessed for prospective homeowners, developers, investors, or tax assessors. The cost and sale price comparison are the traditional real estate valuation method however it lacks the accepted standards and certification [5]. A good model is necessary to fill up a critical information gap and improve the competency of the real estate market.

In this study, the focus is on evaluating the value of real estate asset for the double-storey terrace houses in Johor, Malaysia. Land and the building on the land are two different subjects that need to be evaluated separately. There are many approaches and models used in assessing the value of real estate assets, but its accuracy is questionable and may not lead to a win-win situation. The Valuation and Property Services department (JPPH), Ministry of Finance of Malaysia is the only government body that conducts the valuation of the real estate assets. 
Assessment can only be done by the State Government, Federal Government, Statutory Bodies and Local Authorities. Many real estate owners and investment fund managers found difficulties to get the appraisal for the real estate assets by JPPH due to the high volume of request. The only way for the public to estimate the market value of the asset is by hiring a private appraiser and can be very costly, or they can refer to the property market report from NAPIC published by JPPH.

The process to evaluate the value of the real estate is very complicated and challenging because of the many factors that contribute to the depreciation or an increment in the value of assets. These factors include the age of the building, floor area, and distance from the nearest town centre and others. However, there are some basic models to calculate the value of the buildings, and it is currently used by the developers in Malaysia.

Most of these models require a strong understanding and knowledge in mathematical or statistical methods. Currently, there is no easy mathematical model to estimate the value of the real estate assets in Malaysia that can be used by all. There are two methods in the valuation of a real estate asset, which are traditional valuation method and the advanced valuation method.

The traditional valuation methods include ordinary least squares (OLS), multiple regression method (MRM), comparable method, profit method, development method and cost method while for the advanced valuation methods includes the Hedonic pricing method, spatial analysis method, artificial neural networks (ANNs), and fuzzy logic method [6].

Regression methods such as ordinary least squares (OLS) and multiple regression models (MRM) have been widely applied in the valuation of real estate assets in the USA and Australia [7]. These methods possess the ability to generate value and describe the value of the objective of an appraisal [8]. The value of land derives from its utilization and anything that affects the productivity of land will be reflected in its purchase price. In principle, land price contains information on the value that is stated by the owner based on various characteristics of the land. Using the Hedonic approach, price differentials associated with a component are used to measure the productivity value [9]. The Hedonic pricing model is the extension of the OLS and MRM model.

There is another popular method that is being used by many appraisers. This hybrid method where it is a combination of the Hedonic model and Automated Valuation Model (AVM). This method is developed by using the mathematical model and by determining the value of the land and building separately, the model was customized based on a computer software program that produces an estimate of the market value of the real estate assets [10]. AVM method does not take into consideration the state of the property. Besides, the result produced from the evaluation is based on average conditions that may not reflect the real price [11]. By using the Hedonic model as a basic model and Minkowski distance approach, AVM is challenging to practice and understand.

In Malaysia, the sales comparison method is the method that is widely used for the appraisal of real estate assets [12]. The comparison method is fundamental to traditional evaluation methods. Appraisers are only able to examine a comparison of very similar assets and very close to a lot of asset valuation. Based on the European and North American literature the sale comparable method is a precise and reliable estimated method [13]. This method is very helpful in instances where there is a lack of information. The other method is the summation approach. The concept of this theory is the value of a property can be estimated by summing the land value and the physical structure value with their depreciation value. The method also can be a hybrid by combining the cost approach with the sales comparison approach. For instance, the cost to construct a building can be determined by adding the material, labour, depreciation and other costs. Meanwhile, the examination of comparable sales data can be used for derivation of land values.

This study is to propose a mathematical model for the valuation of double-storey houses using the summation method and to verify the model by valuing the double-storey terrace houses in Johor, Malaysia.

There are three stages involved in this research that are the assumptions made about the model, the formulation of the model, and verification of the proposed model.

\section{MODELING}

There are several assumptions made in valuing the house and they are described as follows:

I. The useful lifespan of the physical structure is $T$ where, $T \neq 0$.

II. Only the rate of construction for the building excluding porch and veranda $\left({ }^{G_{1}}\right)$ and the porch and veranda $\left(G_{2}\right)$ are considered in this study.

III. The useful life of a building/physical structure is 50 years [14].

IV. The total depreciation $D$, for a physical structure value, depreciated until 50 years of useful life and after that, the physical structure value will remain constant at the residual value.

V. This formula ignores any renovation cost and maintenance cost. 
VI. The comparable subjects for the land must be in the same neighbourhood and it must be less than 6 months from the date of sales.

There are three factors required to appraise the value of double-storey terrace houses. The factors are the value of the land, value of the physical structures and value of the house.

\section{Value of the land.}

One of the methods in computing land values is the TOPSIS method. To suit this method in the study, the alternatives and the criteria need to be set first. The comparable subject $A_{i}$ where $i=1,2,3$ are set as the alternatives and $C_{j}$ as the criteria where $j=1,2,3$. In this study, the price per square feet is represented as $C_{1}$, the distance from the subject is $C_{2}$ and the difference in land area is $C_{3}$. From the alternatives and the criteria, the decision matrix $\mathbf{H}$ is formed as below:

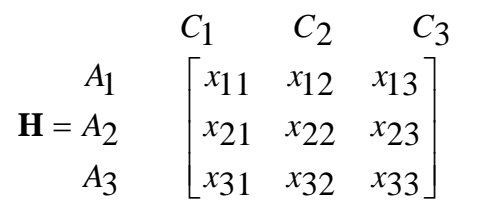

The normalize decision matrix $\mathbf{R}_{\text {where }} R_{i j} \in \mathbf{R}$ such that

$$
R_{i j}=\frac{x_{i j}}{\sqrt{\sum_{i=1}^{3} x_{i j}^{2}}} .
$$

The weightage is denoted by $W_{j}$ where ${ }^{j=1,2,3}$ and the weighted normalize matrix $\mathbf{N}_{\text {where }} N_{i j} \in \mathbf{N}$ is computed by multiplying weightage ${ }^{W_{j}}$ with the normalize decision matrix $\mathbf{R}$.

$$
N_{i j}=W_{j} \times R_{i j}
$$

From the weighted normalize matrix $\mathbf{N}$, the positive ideal solution $P^{+}$and negative ideal solution $P^{-}$are determined by using the formulae below:

$$
\begin{aligned}
P^{+} & =\left\{\left(\max N_{i 1}, \min N_{i 2}, \min N_{i 3}\right)\right\} \\
& =\left\{P_{1}^{+}, P_{2}^{+}, P_{3}^{+}\right\}
\end{aligned}
$$

where $i=1,2,3$. 
The price per square feet $C_{1}$ is classified as the benefits criterion where the maximum value in this column is chosen as the $P_{1}^{+}$and for both distances from the subject $C_{2}$ and the difference in land area ${ }^{C_{3}}$ are classified as the cost criteria where the minimum value in each column are chosen to become $P_{2}^{+}$and $P_{3}^{+}$respectively. Opposite to $P^{+}$, the formula for $P^{-}$is:

$$
\begin{aligned}
P^{-} & =\left\{\left(\min N_{i 1}, \max N_{i 2}, \max N_{i 3}\right)\right\} \\
& =\left\{P_{1}^{-}, P_{2}^{-}, P_{3}^{-}\right\}
\end{aligned}
$$

where $i=1,2,3$.

Subsequently, the positive separation measure $S_{i}^{+}$is computed by using the formula

$$
S_{i}^{+}=\sqrt{\sum_{j=1}^{3}\left(N_{i j}-P_{j}^{+}\right)^{2}}
$$

where $i=1,2,3$ and the negative separation measure $S_{i}^{-}$

$$
S_{i}^{-}=\sqrt{\sum_{j=1}^{3}\left(N_{i j}-P_{j}^{-}\right)^{2}}
$$

where $i=1,2,3$.

The values of $S_{i}^{+}$and $S_{i}^{-}$then were used to calculate the relative closeness to the ideal solution $C_{i}^{*}$ by using the formula (4.8). $C_{i}^{*}=\frac{S_{i}^{-}}{\left(S_{i}^{+}+S_{i}^{-}\right)}, \quad 0<C_{i}^{*}<1$,

where $i=1,2,3$. After that, the values of $C_{i}^{*}$ need to be converted into the percentage form.

The last step in TOPSIS method is determining the preference order of $C_{i}^{*}$ from the highest value to the lowest value. The highest value of $C_{i}^{*}$ is then chosen to be the preferred value $F$ for the subject land to calculate the land value $L$. The formula for $L$ is as the following where $M$ is the land area.

$L=F \times M$

\section{Value of The Physical Structures.}

A personal interview was conducted with the expert. The interview discussed the methods used by the appraisers in Malaysia, factors and elements that affect the value of the physical structure such as cost, built up area, depreciation, incidental cost, residual 
value, time, instalment value and others. The construction costs for the various house sizes or buildings were referred to the annual report published by the Ministry of Work Malaysia (2015) in [4] and the construction rates were referred to the developer in each location.

This section proposes the mathematical model in estimating the value of the physical structures based on the construction cost of the buildings. The square foot method or cost approach was used in this study. The appraisers refer to the rate of the construction costs per square foot of various sizes of houses or buildings that was published by the Ministry of Work Malaysia in 2015 [4]. The quantity $B_{i}$ is denoted as the build-up area of a house per square feet where $i=1,2,3 \ldots n$ and $G_{i}$ is the construction rate per square feet of the building where $i=1,2,3 \ldots n$. In this study, $i=1$ for the building, excluding porch and veranda and $i=2$ is the porch and veranda were considered. To get the gross value of the physical structure $V$, the build-up area of house per square feet was multiplied by the construction rate per square feet as below:

$$
V=\left(B_{1} \times G_{1}\right)+\left(B_{2} \times G_{2}\right)
$$

Other than the cost of construction of the building, the external facilities and special operating facilities shoud be considered in the valuation of the physical structures. The sum is increased by 15 percent for the incidental cost [15]. Denote I as an incidental cost and $\mathrm{r}$ as the rate of increment. Then the formula of incidental cost $\mathrm{I}$ is

$$
I=r \times V
$$

The next step is to subtract the depreciation of the physical structures. Depreciation method used in this project is the straight-line depreciation method. In the straight-line depreciation method, the depreciation value for a year is obtained from the gross value of the physical structure $V$ with incidental cost $I$ which is (the total cost of physical structure) subtract with the residual value $R$, and then it is divided by the useful life $T$ of the physical structure [16]. The total depreciation $D$ is the depreciation value for a year is multiplied by the age of the physical structure $t$ by year, and then the formula for the total depreciation is as follows:

$$
\begin{aligned}
D & =[((V+I)-R) \times(1 / T)] \times t \\
& =\frac{((V+I)-R) t}{T} .
\end{aligned}
$$

The residual value $R$ or another name is scrap value is the remaining value of an asset after it has fully depreciated. The residual value $R$ is 10 per cent of the total cost of the physical structure [17]. The variable $s$ represents the percentage of residual value $R$ out of the total cost of the physical structure which is 10 per cent and the formula of the residual value $R$ is as follows:

$$
R=(V+I) \times s
$$

The total value of the physical structure $K$ is obtained from the gross value of physical structure $V$ adds to the incidental cost $I$ then subtract with the depreciation $D$ like equation below:

$$
K=V+I-D
$$

By substituting equation (12) into equation (14), the physical structure value $K$ becomes

$$
K=V+I-\frac{((V+I)-R) t}{T} .
$$

Then substitute equation (11) and (13) into equation (15), the value of physical structure $\mathrm{K}$ is

$$
\begin{aligned}
K & =V+r V-\frac{((V+r V)-(V+r V) s) t}{T} \\
& =V(1+r)-\frac{t(V(1+r)-V(s+r s))}{T} \\
& =V(1+r)-\frac{V t((1+r)-(s+r s))}{T} \\
& =V(1+r)-\frac{V t(1+r-s-r s)}{T}
\end{aligned}
$$




$$
=V\left[(1+r)-\frac{t(1+r-s-r s)}{T}\right] \text {. }
$$

The final formula for physical structure value also can be obtained by substituting equation (10) into equation (16) is as follows:

$$
K=\left[\left(B_{1} G_{1}\right)+\left(B_{2} G_{2}\right)\right]\left[(1+r)-\frac{t(1+r-s-r s)}{T}\right]
$$

Where $T \neq 0$.

\section{Value of the house.}

In this study, the summation method is used. This method is the sum of the land value $L$ and the value of the physical structures $K$ at the date of sale. Denote $Q$ as the value of the house that is equal to the summation land value $L$ with the value of the physical structures of the building $K$,

$Q=L+K$.

Then, substitute equation (16) into equation (17) to obtain the final formula as follow:

$Q=L+\left[\left(B_{1} G_{1}\right)+\left(B_{2} G_{2}\right)\right]\left[(1+r)-\frac{t(1+r-s-r s)}{T}\right]$.

where $T \neq 0$.

If the age of the physical structure exceeds 50 years old, then the formula is as follow:

$Q=L+R$.

\section{RESULTS AND DISCUSSION}

The data for the valuation of the real estate asset for the double-storey terrace houses in Johor was collected while the sales comparison approach for land were collected from the developer for each terrace house in ten districts in Johor. From each district, at least, three land prices with most comparable sales from the same neighbourhood were collected. Next, the current cost construction of

the building in Malaysia was identified which includes material, labour and another cost. The market prices of the double-storey terrace houses were collected from the annual report published by JPPH. There are ninety-three places from ten districts in Johor as shown in Appendix 1.

The data for the sales comparison approach for land valuation was collected from the JPPH annual report and from the developer for each terrace house in ten districts in Johor. Not all the data exist in the report and for the unknown land value at least three land prices with most comparable sales from same neighbourhood were collected. The land area of double-storey terrace house at Taman Bandar Baru Uda is 1,647 square feet and the equivalent subjects to this land are in Table 1.

Table 1 is the information on the comparable subjects to the land at Taman Bandar Baru Uda. The entire comparable subjects' date of sales must be less than six months. After the data was collected, the TOPSIS methods were used to obtain the land value. For illustration, the land value of a unit double-storey terrace house at Taman Bandar Baru Uda will be computed. At first, the decision matrix (1) was formed as follows: 


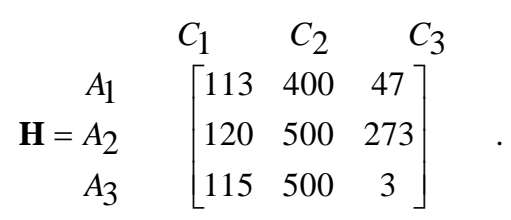

The equation (2) is used to find the normalize decision matrix $\mathbf{R}$ as below:

$$
R_{11}=\frac{113}{\sqrt{(113)^{2}+(120)^{2}+(115)^{2}}=0.561} \quad \begin{array}{r}
C_{1} \\
A_{1}
\end{array} \quad \begin{array}{ccc}
C_{2} & C_{3} \\
A_{2} & A_{3}
\end{array}\left[\begin{array}{ccc}
0.561 & 0.492 & 0.170 \\
0.574 & 0.615 & 0.985 \\
0.615 & 0.011
\end{array}\right] .
$$

Next, the weightage of each criterion required.

Table 1: The Information about Comparable Subjects to Taman Bandar Baru Uda

\begin{tabular}{|c|c|c|c|c|c|}
\hline & $\begin{array}{l}\text { Selling Price } \\
\text { (RM) }\end{array}$ & $\begin{array}{c}\text { Land Area } \\
\text { (Sq. Ft.) }\end{array}$ & $\begin{array}{c}\text { Price per square feet (RM) } \\
C_{1}\end{array}$ & $\begin{array}{c}\text { Distance from Subject (meter) } \\
C_{2}\end{array}$ & $\begin{array}{c}\text { Difference in land area } \\
C_{3}\end{array}$ \\
\hline Subject $A_{1}$ & 180,000 & 1,600 & 113 & 400 & 47 \\
\hline Subject $A_{2}$ & 230,000 & 1,920 & 120 & 500 & 273 \\
\hline Subject $A_{3}$ & 190,000 & 1,650 & 115 & 500 & 3 \\
\hline
\end{tabular}

The weightage in Table 2 was determined after having interviewed a real estate lawyer.

Table 2: Weightage of Each Criteria

\begin{tabular}{|c|c|c|c|}
\hline & Price per (sq. ft) (RM) $C_{1}$ & Distance from Subject (meter) $C_{2}$ & The difference in land area $C_{3}$ \\
\hline Weight & 0.3 & 0.4 & 0.3 \\
\hline
\end{tabular}

Based on this set of weight using the equation (3), the weightage normalise decision matrix $\mathbf{N}$ is

\begin{tabular}{|c|c|c|c|}
\hline & $C_{1}$ & $C_{2}$ & $C_{3}$ \\
\hline$A_{1}$ & {$[0.168$} & 0.197 & 0.051 \\
\hline $\mathbf{N}=A_{2}$ & 0.179 & 0.246 & 0.296 \\
\hline$A_{3}$ & 0.172 & 0.246 & 0.003 \\
\hline
\end{tabular}

Equations (4) and (5) are used to calculate the positive and negative ideal solution. The positive ideal solution is

$$
P^{+}=(0.179,0.197,0.003)
$$

and the negative ideal solution is

$$
P^{-}=(0.168,0.246,0.296)
$$

By using equation (6) and (7), the separation measure is calculated as below:

The positive ideal solution $S_{1}^{+}, S_{2}^{+}$and $S_{3}^{+}$: 


$$
\begin{aligned}
S_{1}^{+} & =\sqrt{(0.168-0.179)^{2}+(0.197-0.197)^{2}+(0.051-0.003)^{2}} \\
& =0.0489 \\
S_{2}^{+} & =0.2965 ; S_{3}^{+}=0.0497 .
\end{aligned}
$$

The negative ideal solution $S_{1}^{-}, S_{2}^{-}$and $S_{3}^{-}$:

$$
\begin{aligned}
S_{1}^{-} & =\sqrt{(0.168-0.168)^{2}+(0.197-0.246)^{2}+(0.051-0.296)^{2}} \\
& =0.2496
\end{aligned}
$$

$S_{2}^{-}=0.0109 ; S_{3}^{-}=0.2924$.

Then, the relative closeness to ideal solution $A_{1}, A_{2}$

and ${ }^{A} 3$ are calculated by using equation (8):

$$
\begin{aligned}
& A_{1}=\frac{0.2496}{(0.0489+0.2496)} \\
& A_{1}=0.8362 \\
& A_{2}=0.0354 ; A_{3}=0.8547 .
\end{aligned}
$$

The percentage values of ${ }^{A_{1}},{ }^{A_{2}}$ and ${ }^{A_{3}}$ are

$$
\begin{aligned}
& A_{1}=0.8362 \times 100, A_{2}=0.0354 \times 100, A_{3}=0.8547 \times 100 \\
& A_{1}=83.62 \%, A_{2}=3.54 \%, A_{3}=85.479 \% .
\end{aligned}
$$

Then, the preferred order of alternative is as below:

$A_{3}<A_{1}<A_{2}$.

Since ${ }^{A_{3}}$ has the highest percentage, concluding that the comparable subject ${ }^{A_{3}}$ is highly related to the subject land. Therefore, the comparable subject ${ }^{A} 3$ was chosen with the price RM115 per square feet to represent the preferred value $F$ for the subject land of double-storey terrace house at Taman Bandar Baru Uda. Since the value of $M$ is 1,647 square feet, the value of land was computed using equation (9) as follows:

$$
\begin{aligned}
L & =1,647 \times 115 \\
& =R M 189,405 \approx R M 190,000 .
\end{aligned}
$$

Hence, the land value of a double-storey terrace house at Taman Bandar Baru Uda is RM190,000. After that, the current cost construction of the building in Malaysia which includes material, labour and other cost was obtained. This construction rate was collected from the developers for each district in Johor. Below is the Table 3 that provides the research information of the construction rate in Johor.

Table 3: Construction Rate in Johor

\begin{tabular}{|c|c|}
\hline Places & Construction rate (sq. ft.) (RM) \\
\hline Small towns and simple design & $70-134$ \\
\hline Big city or any complicated design & $135 \geq$ \\
\hline Porch or veranda & $30-75$ \\
\hline
\end{tabular}


In this study, the rate is inclusive of labor, construction materials, electrical wiring system and piping systems for water supply, contractor profit and the management cost. Based on the data collected, a summary is shown in Table 4 as follows:

Table 4: Summarized Information for Taman Bandar Baru Uda

\begin{tabular}{|c|c|c|c|c|c|}
\hline $\begin{array}{c}\text { Total build-up } \\
\text { area (sq. ft.) }\end{array}$ & $\begin{array}{c}\text { Build up } \\
\text { area (sq. ft.) }\end{array}$ & $\begin{array}{c}\text { Porch or } \\
\text { veranda area } \\
\text { (sq. ft.) }\end{array}$ & $\begin{array}{c}\text { Construction cost for build up } \\
\text { area (sq. ft.) (RM) }\end{array}$ & $\begin{array}{c}\text { Construction cost for porch/ } \\
\text { veranda (sq. ft.) (RM) }\end{array}$ & $\begin{array}{c}\text { Age of the } \\
\text { building (s) }\end{array}$ \\
\hline 1,819 & 1,516 & 303.17 & 135 & 70 & 5 \\
\hline
\end{tabular}

Table 4 shows all information about building the structure and the price of construction. All the age of the building in year $\mathrm{s}$ is assumed as 5 years. From the data above, the gross value of physical structure $\mathrm{V}$ is found by using equation (10):

$$
\begin{aligned}
V & =(1,516 \times 135)+(303 \times 70) \\
& =\text { RM } 225,870 .
\end{aligned}
$$

Then the summation method was applied to obtain the final value of a double-storey terrace house at Taman Bandar Baru Uda. Based on the land value and the physical structure the value of $\mathrm{Q}$ is computed :

$$
\begin{aligned}
Q & =190,000+225,870\left[(1+0.15)-\frac{5(1+0.15-0.1-0.015)}{50}\right] \\
& =190,000+225,870(1.0465) \\
& =R M 426,373 .
\end{aligned}
$$

\begin{tabular}{|c|c|c|c|c|c|}
\hline No & District & Land value (RM) & $\begin{array}{c}\begin{array}{c}\text { Valuation } \\
(\mathbf{R M})\end{array} \\
\end{array}$ & Market value (RM) & Percentage error $(\%)$ \\
\hline & Johor Bahru & & & & \\
\hline 1 & Bandar Baru UDA & $* 190,000$ & 426,375 & 440,000 & 0.031 \\
\hline 2 & Bandar Baru Permas Jaya & $* 230,000$ & 400,637 & 486,000 & 0.176 \\
\hline 3 & Bandar Baru Seri Alam & 120,000 & 343,787 & 360,000 & 0.045 \\
\hline 4 & Bandar Dato’ Onn & $* 160,000$ & 346,023 & 380,000 & 0.089 \\
\hline 5 & Bandar Jaya Putra & $* 220,000$ & 400,428 & 450,000 & 0.110 \\
\hline 6 & Bandar Selesa Jaya & 120,000 & 313,016 & 350,000 & 0.106 \\
\hline 7 & Austin Boulevard & $* 240,000$ & 433,016 & 530,000 & 0.183 \\
\hline 8 & Horizon Hill & 130,000 & 383,159 & 410,000 & 0.065 \\
\hline 9 & Taman Air Biru & 90,000 & 213,083 & 250,000 & 0.148 \\
\hline 10 & Taman Austin Perdana & $* 240,000$ & 417,631 & 480,000 & 0.130 \\
\hline 11 & Taman Bukit Indah & $* 250,000$ & 389,867 & 410,000 & 0.049 \\
\hline 12 & Taman Bukit Kempas & 80,000 & 260,428 & 300,000 & 0.132 \\
\hline 13 & Taman Bukit Mewah & 90,000 & 271,827 & 320,000 & 0.151 \\
\hline 14 & Taman Bukit Tiram & 70,000 & 218,259 & 240,000 & 0.091 \\
\hline 15 & Taman Daya & 90,000 & 301,583 & 365,000 & 0.174 \\
\hline 16 & Taman Desa Cemerlang & $* 110,000$ & 353,368 & 375,000 & 0.058 \\
\hline 17 & Taman Desa Harmoni & 80,000 & 261,827 & 300,000 & 0.127 \\
\hline 18 & Taman Desa Jaya & 50,000 & 231,827 & 260,000 & 0.108 \\
\hline 19 & Taman Desa Tebrau & $* 220,000$ & 382,245 & 450,000 & 0.151 \\
\hline 20 & Taman Desa Skudai & 50,000 & 241,617 & 260,000 & 0.071 \\
\hline : & Segamat & $:$ & $:$ & $:$ & $:$ \\
\hline 92 & Bandar Putra & 90,000 & 229,397 & 245,000 & 0.064 \\
\hline \multirow[t]{2}{*}{93} & Bandar Segamat Baru & 90,000 & 239,723 & 360,000 & 0.078 \\
\hline & Average MAPE & & & & 9.041 \\
\hline
\end{tabular}

So, the valuation value of terrace house at Taman Bandar Baru Uda is RM426,373.

Table 5: Summarized Result for Valuation and the Mean Absolute Percentage Error

Note: (*) at the land values are found by using TOPSIS method. 
Table 5 shows the summarized results for the valuation of the double-storey terrace houses in Johor. Then the comparison between the valuation prices and the market prices are then illustrated in the graph like Figure 1.

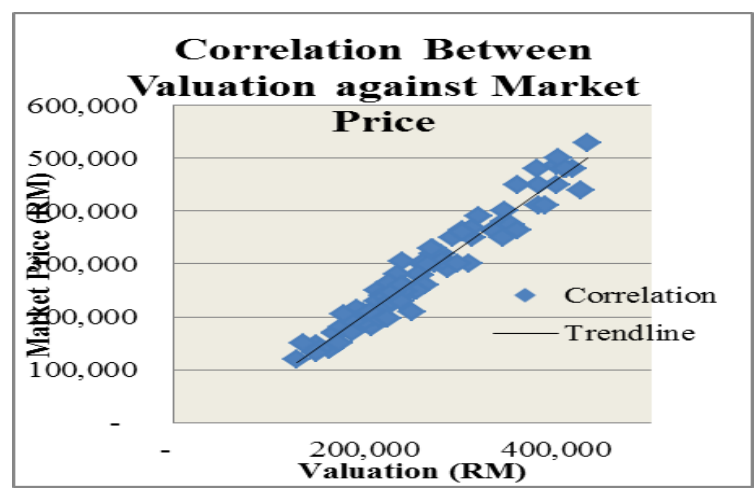

Figure 1: Correlation Between Valuation and the Market Price

Based on Figure 1 above, the trend line for the valuation against the market price shows that the values are very close to each other. The correlation coefficient value is +0.97 . Since the value is close to +1 , the relationship between the valuation and the market price is a very strong positive correlation. The average MAPE of prices for overall places are $9.041 \%$ where it is below $10 \%$ and this outcome can be judged as highly accurate valuation. This study only shows the big picture of how to appraise the value of the double-storey terrace houses. The values might not be too accurate if compared to the market price, but the percentage error obtained here to claim this method as acceptable.

\section{CONCLUSION}

This study proposes a new valuation model for real estate assets. The proposed model is a hybrid between the land value and the physical structure value of a real estate asset that is determined separately.

The land value is determined by using the TOPSIS method and this method is only used for the unknown land value. The values of the physical structure were determined by using the cost approach. This study combines all the elements that are related to the valuation of a physical structure.

The verification of the model in this study used the historical data from the Malaysian Price Index published by NAPIC and from several surveys. As a result, the value of the double-storey

terrace houses in Johor have shown a powerful positive linear correlation with the market prices where the correlation coefficient value is +0.97 . The values of MAPE in certain places in Johor are quite high since the standardized construction rates were used. However, the MAPE for overall places is $9.041 \%$ where it is below $10 \%$ and this outcome can be judged as a highly accurate valuation. Based on the correlation coefficient and the MAPE value, thereby, this model is acceptable.

\section{ACKNOWLEDGEMENT}

The authors would like to acknowledge the financial support received from the Ministry of Higher Education of Malaysia, the Fundamental Research Grant Scheme 600-RMI/FRGS 5/3(83/2016) Universiti Teknologi MARA.

\section{REFERENCES}

[1] Galloway, C. (2014). Emerging Trends in Real Estate® Asia Pacific 2014 - PwC.

[2] NAPIC, National Property Information Centre. (2015). Malaysian price index 2015. Valuation and Property Services Department.

[3] Oxford Dictionary (2013)

[4] Ministry of Natural Resources and Environment. (2015). National Land Code (Act 56 Of 1965). Malaysia: Department of Director General of Land and Mines, 1966.

[5] Limsombunchai, C.G,. \& Minsoo L. (2004). House price prediction Hedonic: price model vs. artificial neural network. American Journal of Applied Sciences, 1(3), 45-46. 
[6] Pagourtzi, E., French, V., Thomas, A., \& Hatzichristos N. (2003). Real estate appraisal: a review of valuation methods. Journal of Property Investment \& Finance, 21(4), 101-120.

[7] Panayiotou, P.A., Constantinos, P., Pastor D.J., \& Frances P,. (1999). A modular artificial neural network valuation system. Property Tax Assessment and Administration, 4(3), 310-311.

[8] McCluskey, W., \& Anand, S,. (1999). The application of intelligent hybrid techniques for the mass appraisal of residential properties. Journal of Property Investment \& Finance, 17(3), 239-241.

[9] Maddison, D. (2000). A Hedonic analysis of agricultural land prices in England. European Revie od Algricultural Economic, 27(4), 532-534.

[10] Dornfest, A.S., Clark, L.J., Gloudemans, K., Robert, J.C., Michael, W.I., O’Connor, P.M,. \& William M.W. (2003). Standard on automated Valuation Models (AVMs). International Association of Assessing Officers130 East Randolph.

[11]Rispin, C., \& Bradford, T. (2009). Automated Valuation Models. RICS information paper.

[12] Suriatini, I., Abdul Hamid, M.I., Norhaya K., \& Hishamuddin M. (2008). Spartial autocorrelation in hedoni model: emperical evidence from Malaysia. International Real Estate Research Symposium.

[13] Pagourtzi, E., French, V., Thomas, A., \& Hatzichristos N. (2003). Real estate appraisal: a review of valuation methods. Journal of Property Investment \& Finance, 21(4), 101-120.

[14] DCA Office of Affordable Housing. (2011). Expected useful life table. Architectural Manual.

[15] Murle, M. (1995). Assessment of the market value of real estate with private housebuilding derived from the summation method of valuation with adjustment to current market value. Journal of Financial Management of Property and Construction, 2(1), 123-125.

[16] Skousen, K.F., Earl, K.S, \& James, D.S. (2010). Intermediate Accounting. 15th ed. Mason: South-Western.

[17] Fuller, S. (2008). Life-Cycle Cost Analysis (LCCA). National Institute of Standards and Technology (NIST). 